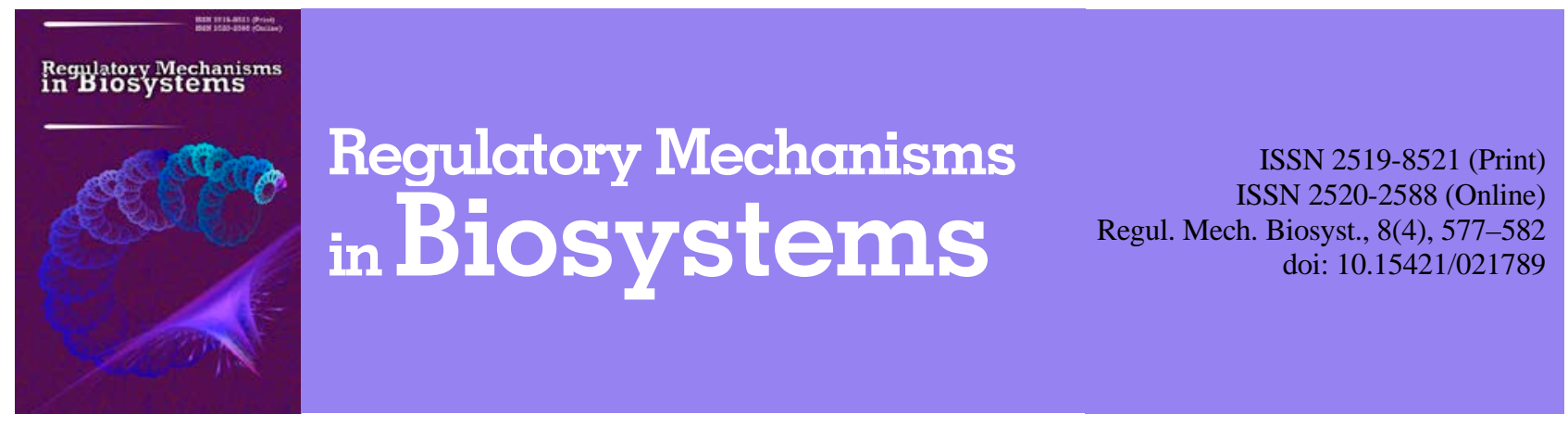

\title{
The effect of antimicrobial agents on planktonic and biofilm forms of bacteria that are isolated from chronic anal fissures
}

\author{
I. M. Kozlovska*, N. Y. Romanjuk**, L. M. Romanjuk**, \\ M. D. Kukhtyn***, Y. V. Horiuk****, G. V. Karpyk*** \\ *Bukovinian State Medical University, Chernivtsi, Ukraine \\ ${ }^{* *}$ I. Y. Horbachevsky Ternopil State Medical Universi, Ternopil, Ukraine \\ ***Ternopil Ivan Puluj National Technical University, Ternopil, Ukraine \\ ****State Agrarian and Engineering University in Podilya, Kamianets-Podilskyi, Ukraine
}

\section{Article info}

Received 08.10.2017

Received in revised form 14.11.2017

Accepted 16.11.2017

Bukovinian State Medical University, Theatralna sq., 2, Chernivtsi, 58002, Ukraine. Tel.: +38-050-670-59-13 E-mail:irkakim5@gmail.com

I. Horbachevsky Ternopyl State Medical University, m. Voli, 1 , Ternopil, 46001, Ukraine. Tel.: +38-097-854-87-81

E-mail: fedchyshyn@tdmu.edu.uo

Ternopil Ivan Puluj National Technical University, Ruska st., 56,

Ternopil, 46001, Ukraine.

Tel.: +38-097-239-20-57

E-mail: kuchtynnic@gmail.com

State Agrarian and Engineering

University in Podilya,

Schevchenko st., 13,

Kamianets-Podilskyi, 32300,

Ukraine.

Tel.: +38-097-661-79-64

E-mail: goruky@ukr.net
Kozlovska, I. M., Romanjuk, N. Y., Romanjuk, L. M., Kukhtyn, M. D., Horiuk, Y. V., Karpyk, G. V. (2017). The effect of antimicrobial agents on planktonic and biofilm forms of bacteria that are isolated from chronic anal fissures. Regulatory Mechanisms in Biosystems, 8(4), 577-582. doi:10.15421/021789

The microorganisms that are formed in biofilm cause about $60 \%$ of chronic and recurrent diseases, and as a consequence, traditional etiotropic antibacterial therapy is ineffective. Chronic anal fissures are also a disease which is caused by biofilm forms of bacteria, has a chronic course and is difficult to treat. The sensitivity of planktonic and biofilm forms of bacteria isolated from chronic anal fissures to antibacterial drugs was determined and the method of degradation of biofilm by electrophoresis for the effective treatment of fissures was developed. It was found that the most effective antibiotics against planktonic forms of bacteria were cephalosporins III and IV generations: cefepime, cefoperazone and ceftazidime. Exceptionally, only bacteria of the genus Enterococcus, which were sensitive to ceftazidime, were found to be $38.9 \%$. The sensitivity of the bacteria to Furamag was from $60.0 \%$ to $100.0 \%$, and only $P$. aeruginosa exhibited resistance in $100.0 \%$ of the studied cultures. The number of sensitive to gatifloxacin strains of P. aeruginosa and Enterobacter spp. was $71.4 \%$, all other isolated bacteria were sensitive to this preparation from $77.8 \%$ to $100.0 \%$. Among the five studied antiseptics (chlorhexidine, decasan, octinisept, povidone iodine, dioxidine), the greatest antimicrobial activity was found in dioxidine and betadine (povidone iodine) solutions, the sensitivity of the microflora was from $60.0 \%$ to $100.0 \%$. We found that the most protected biofilm matrix was $P$. aeruginosa and Enterococcus spp. We found that the antibiotic which had the best effect on cells in biofilm was fluoroquinoione gatifloxacin. After its influence on the biofilm $P$. aeruginosa and Enterococcus spp., the number of living cells didn’t exceed $\lg 1.5 \pm 0.02 \mathrm{CFU} / \mathrm{cm}^{2}$ in the area of the biofilm, and $S$. aureus and E. coli cells were completely inactivated. After the influence of other antibiotics, the number of microbial cells that survived in the biofilm did not exceed $\lg 2.9 \pm 1.6 \mathrm{CFU} / \mathrm{cm}^{2}$ of the area. It was found that after the action of dioxin, the amount of viable microbial cells was up to $\lg 2.9 \pm 1.7 \mathrm{CFU} / \mathrm{cm}^{2}$ of biofilm area. Antiseptics: octine septum, ranopost, decaSan and chlorhexidine exhibited less strong bactericidal action on cells in biofilms, and the number of bacteria that survived after their action ranged from $2.9 \pm 1.8$ to $\lg 3.7 \pm 2.1 \mathrm{CFU} / \mathrm{cm}^{2}$ of biofilm area. We propose using solution "Dioxysol-Darnitsa" (active substance dioxidine) for local treatment of patients with chronic anal fissures for intracutaneous electrophoresis of the fissure. We established that under the influence of electrophoresis at a current of $0.05-0.10 \mathrm{~mA} / \mathrm{cm}^{2}$ of the area of the biofilm with dioxidine, bacteria were not isolated. This indicates on the destruction of the matrix and the effective contact of dioxidine with microbial cells and the manifestation of bactericidal action. Consequently, laboratory microbiological studies indicate that the use of electrophoresis with dioxysole in the treatment of chronic anal fissures is promising.

Keywords: antibiotics; antiseptics; sensitivity; biofilm; electrophoresis; anal fissures

\section{Вплив антимікробних препаратів на планктонні та біоплівкові форми бактерій, виділені з хронічних анальних тріщин}

\author{
І. М. Козловська*, Н. С. Романюк**, Л. М. Романюк**, \\ М. Д. Кухтин***, Ю. В. Горюк****, Г. В. Карпик*** \\ *Буковинський державний медичний університет, Чернівиі, Украӥна \\ **Тернопільський державний медичний університет імені I. Я. Горбачевського, Тернопіль, Украӥна \\ ***Тернопільський національний технічний університет імені I. Пулюя, Тернопіль, Украйна \\ ****Подільський державний аграрно-технічний університет, Кам'янець-Подільський, Україна
}


Визначено чутливість планктонних та біоплівкових форм бактерій, виділених із хронічних анальних тріщин, до антибактеріальних препаратів, розроблено спосіб деградації біоплівки електрофорезом для ефективного лікування дефекту слизової оболонки. Найефективнішими з антибіотиків на планктонні форми бактерій виявилися цефалоспорини III і IV покоління: цефепім, цефоперазон і цефтазидим. Iз п’яти досліджених антисептиків виявлено найбільшу протимікробну дію розчину діоксидину та розчину бетадину (повідонйод): чутливість мікрофлори становила 60-100\%. Із досліджених антибіотиків найкраще впливає на клітини біоплівки гатифлоксацин. Після його дії на біоплівки Pseudomonas aeruginosa i Enterococcus spp. кількість живих клітин не перевищувала $\lg 1,5 \pm 0,02$ КУО/см² площі біоплівки, а клітини Staphylococcus aureus i Escherichia coli повністю інактивовані. Після впливу інших антибіотиків кількість мікробних клітин, що вижили у біоплівці, не перевищувала $\lg 2,9 \pm 1,6$ КУО/см² площі. Після дії діоксидину кількість життєздатних мікробних клітин становила до $\lg 2,9 \pm$ 1,7 КУО/см² площі біоплівки. Запропоновано для місцевого лікування хворих на хронічні анальні тріщини та для внутрішньотканинного електрофорезу тріщин використовувати розчин «Діоксизоль-Дарниця» (діюча речовина діоксидин). Під час електрофорезу силою струму 0,05-0,10 мА/см площі біопліки 3 діоксидином бактерій не виділено. Це вказує на руйнування матриксу та добрий контакт діоксидину 3 мікробними клітинами та прояв бактерицидної дії.

Ключові слова: антибіотики; антисептики; чутливість; біоплівка; електрофорез; анальні тріщини

\section{Вступ}

Нині проблема боротьби із септичними запальними захворюваннями, які мають хронічний перебіг, досить актуальна, оскільки вони спричиняються мікроорганізмами у біоплівці, а традиційна етіотропна антибактеріальна терапія малоефективна (Zhao et al., 2013; Penesyan et al., 2015; Banin et al., 2017; Vorobey et al., 2017). Це пов'язано з тим, що мікроорганізми у біоплівці в 10-100 разів стійкіші до антибактеріальних препаратів за свої планктонні форми (Hoiby et al., 2010; Fuente-Nunez et al., 2013; Manavathu et al., 2014; Kukhtyn et al., 2017). У науковій літературі описано низку чинників, які відповідають за резистентність біоплівкових форм бактерій до антибіотиків. Бактерії у біоплівці мають знижений метаболізм і сповільнену швидкість росту клітин, внаслідок чого антимікробні препарати дифундують із біоплівки швидше, ніж досягається їх дія (Weigel et al., 2007; Hall-Stoodley and Stoodley, 2009). У біоплівці відбувається інактивація антибіотиків позаклітинними полімерами та ензимами та формування за впливом антимікробних препаратів клітин-персистерів (Gostev and Sidorenko, 2010). Також бактерії у біоплівці можуть обмінюватися плазмідами, які містять гени, що відповідають за їх резистентність до антибіотиків (Hall-Stoodley et al., 2004; Atkinson and Williams, 2009; Flemming and Wingender, 2010; Van Acker et al., 2014). Екзополісахариди матриксу біоплівки перешкоджають фагоцитарній активності макрофагів, внаслідок чого фагоцити не діють на бактерії, сформовані у біоплівки (Mah and O’Toole, 2001; Percival et al., 2012; Soto, 2013).

Нині достовірно встановлено роль біоплівок у розвитку понад 60\% хронічних або рецидивуючих захворювань, в патогенезі яких бере участь мікробний чинник (Sanchez et al., 2013). Для мікроорганізмів перебування у стані біоплівки, який характеризується прикріпленням до будь-якої поверхні, що омивається - базова властивість, яка виробилася впродовж мільйонів років за впливу природного відбору та змінних екологічних чинників (Atkinson and Williams, 2009; Bessa et al., 2015). Тому нині науковці вважають, що ефективність будь-якого антимікробного препарату чи способу лікування слід перевіряти на адгезованих мікроорганізмах і вважати ефективними ті концентрації (дози), які діють бактерицидно на більшість бактерій у біоплівках, а не на планктонні їх форми (Levis, 2001; Cooper et al., 2014; Kukhtyn et al., 2017).

До захворювань, які мають хронічний перебіг і важко лікуються, відносять хронічні анальні тріщини (XАT) (Ebinger et al., 2017; Stewart et al., 2017; Wienert et al., 2017). Проте наразі дослідники недостатньо звертають увагу на роль біоплівкових форм бактерій у виникненні ХАТ. Тому вивчення видового складу мікрофлори ХАТ, здатність ізольованих бактерій формувати біоплівки та розроблення ефективних методів терапевтичного впливу на біоплівки - ключові питання лікування цієї патології.

Мета дослідження - визначити чутливість планктонних і біоплівкових форм бактерій, виділених із ХАТ, до антибактеріальних препаратів і розробити спосіб деградації біоплівки електрофорезом для ефективного лікування тріщин.

\section{Матеріал і методи досліджень}

Виділення та ідентифікація мікроорганізмів. Для виділення стафілококів змиви 3 ХАТ засівали на середовище жовтково-сольовий м'ясопептонний агар. Виділення ентерококів проводили на середовищі Bile Esculin Azide Agar, стрептококів - Streptococcus Selective Agar (HiMedia). Ентеробактерії (ешерихії, протеї, клебсієли та інші) вирощували на середовищах Ендо, Левіна та Плоскірєва (Фармактив). Виділення Pseudomonas aeruginosa проводили на середовищі Pseudomonas Isolation Agar (HiMedia). Ідентифікацію виділених чистих культур проводили за морфологічними, тинкторіальними, культуральними, біохімічними властивостями та ознаками патогенності. Посіви інкубували в термостаті за температури $37^{\circ} \mathrm{C}$ упродовж 24-48 годин. Ідентифікацію чистих культур проводили, враховуючи біохімічні тести, описані у визначнику бактерій Берджі (Vos et al., 2011).

Визначення щільності утворених біоплівок. У стерильні одноразові пластикові чашки Петрі вносили $5 \mathrm{~cm}^{3}$ м'ясопептонного бульйону та $1 \mathrm{~cm}^{3}$ добової тест-культури мікроорганізмів (Staphylococcus aureus, Enterococcus spp., Enterobacter spp., Escherichia coli, P. aeruginosa) у концентрації $10^{5} \mathrm{KУO} / \mathrm{cm}^{3}$ та інкубували за температури $37{ }^{\circ} \mathrm{C}$ упродовж 24-48 годин. Після інкубації чашки триразово відмивали від планктонних (неприкріплених) мікроорганізмів фосфатним буфером, висушували та фіксували утворені біоплівки $96^{\circ}$ етиловим спиртом упродовж 10 хвилин. Потім забарвлювали $0,1 \%$ розчином кристалічного фіолетового впродовж 10 хвилин. У чашки Петрі додавали $3,0 \mathrm{~cm}^{3} 96^{\circ}$ етилового спирту та залишали на 20-30 хвилин, періодично струшуючи. Вимірювали оптичну густину спиртового розчину спектрофотометрично за довжини хвилі 570 нМ (Stepanovic et al., 2000). За густини промивного розчину з біоплівок до 0,50 од. щільність сформованих біоплівок вважали низькою, від 0,51 до 1,00 од. - середньою та за густини розчину понад 1,01 од. - високою (Kukhtyn et al., 2017).

Визначення чутливості мікроорганізмів, що перебувають у біоплівковій формі, до антибіотиків і антисептиків проводили на добових мікробних біоплівках, вирощених у пластикових чашках Петрі. Після 24 годин інкубації культур чашки триразово відмивали від планктонних (неприкріплених) мікроорганізмів стерильним фосфатним буфером і вносили $5 \mathrm{~cm}^{3}$ свіжоприготовлених антибіотиків або антисептиків. Після експозиції антибіотики та антисептики зливали, чашки триразово промивали стерильним фосфатним буфером, вносили $5 \mathrm{~cm}^{3}$ стерильного $0,9 \%$ розчину натрію хлориду та стерильним тампоном ретельно відмивали зі стінок і дна чашки мікробну біоплівку. Із чашок відбирали $1,0 \mathrm{~cm}^{3}$ суспензії, готували низку десятикратних розведень, проводили посів $1,0 \mathrm{~cm}^{3}$ кожного розведення у чашки Петрі, заливали МПА та інкубували за температури $37^{\circ} \mathrm{C}$ упродовж 24-48 годин для визначення кількості бактерій (Cucarella et al., 2004).

Визначення чутливості планктонних мікроорганізмів, виділених із хронічних ран, до антибіотиків проводили класичним диск-дифузійним методом Кірбі - Бауера. Визначення чутливості планктонних мікроорганізмів до антисептиків проводили таким способом. Готували суспензії $з$ чистих культур, висівали суспензії в чашки Петрі з МПА, виготовляли в МПА лунки за 
допомогою пробійника № 10, заповнювали лунки антисептиками. Чашки Петрі інкубували в термостаті упродовж 24 годин, потім оцінювали результат за діаметром затримання росту мікроорганізмів навколо лунки. Діаметр до 15 мм - мікроорганізми нечутливі до антисептиків, від 16 до 20 мм - мікроорганізми помірно чутливі до антисептиків, від 21 до 25 мм - мікроорганізми чутливі до антисептиків, від 26 мм і більше - мікроорганізми високочутливі до антисептиків (Kukhtyn et al., 2014).

Вивчення впливу електрофорезу різної сили струму на бактерій, які перебувають у біоплівковій формі, проводили за власною методикою. Вирощували мікробні біоплівки у стерильних одноразових чашках Петрі. Після відмивання планктонних клітин фосфатним буфером вносили у чашки з біоплівками $5 \mathrm{~cm}^{3}$ стерильного $0,9 \%$ розчину натрію хлориду, вставляли електроди та підключали прилад «Поток-1». Тривалість дії - 60 хвилин, сила струму - 0,025-0,100 мА/см² площі чашки Петрі. Після закінчення дії електрофорезу з чашок Петрі зливали фізрозчин і змивали відшаровані мікробні біоплівки стерильним фосфатним буфером. Потім вносили $5 \mathrm{~cm}^{3}$ стерильного $0,9 \%$ розчину натрію хлориду та стерильним тампоном ретельно відмивали зі стінок і дна чашки мікробну біо- плівку. Із чашок відбирали $1,0 \mathrm{~cm}^{3}$ суспензії, готували десятикратні розведення, висівали $1,0 \mathrm{~cm}^{3}$ кожного розведення у чашки Петрі, заливали МПА та інкубували за температури $37{ }^{\circ} \mathrm{C}$ упродовж 48 годин для визначення кількості бактерій. Для визначення впливу електрофорезу з антисептиком діоксизолем на мікробні біоплівки дослідження проводили аналогічно, тільки електроди занурювали в чашки Петрі з біоплівками не у фізрозчин, а в діоксизоль.

Статистичну обробку результатів здійснювали методами варіаційної статистики з використанням програми Statistica 6.0 (StatSoft Inc., USA). Застосовували непараметричні методи досліджень (критерії Уїлкоксона, Манна - Уїтні). Визначали середне арифметичне (х), стандартну похибку середньої величини (SE). Різницю між порівнюваними величинами вважали достовірною за $\mathrm{P}<0,05$.

\section{Результати}

Проведено порівняльні дослідження чутливості виділених бактерій, які перебувають у планктонному стані (табл. 1) та у сформованих біоплівках (табл. 2), до антимікробних препаратів.

\section{Таблиця 1}

Чутливість (\%) планктонних форм бактерій, виділених із хронічних анальних тріщин до антимікробних препаратів

\begin{tabular}{|c|c|c|c|c|c|c|c|}
\hline \multirow{2}{*}{$\begin{array}{l}\text { Антимікробні препарати, } \\
\text { кількість діючої речовини }\end{array}$} & \multicolumn{7}{|c|}{ Досліджені бактерії } \\
\hline & $\begin{array}{c}\text { P. aeruginosa, } \\
\mathrm{n}=7\end{array}$ & $\begin{array}{l}\text { E. coli, } \\
\mathrm{n}=34\end{array}$ & $\begin{array}{c}\text { S. aureus, } \\
\mathrm{n}=6\end{array}$ & $\begin{array}{c}\text { Enterococcus } \\
\text { spp., } \mathrm{n}=18\end{array}$ & $\begin{array}{c}\text { Proteus spp., } \\
\mathrm{n}=10\end{array}$ & $\begin{array}{c}\text { Enterobacter spp., } \\
\mathrm{n}=3\end{array}$ & $\begin{array}{c}\text { Citrobacter spp., } \\
\mathrm{n}=3\end{array}$ \\
\hline Цефепім, 30 мкг & 87,7 & 91,2 & 83,3 & 83,3 & 100,0 & 100,0 & 100,0 \\
\hline Цефтазидим, 30 мкг & 100,0 & 91,2 & 100,0 & 38,9 & 100,0 & 100,0 & 100,0 \\
\hline Цефоперазон, 75 мкг & 71,4 & 91,2 & 100,0 & 88,9 & 100,0 & 100,0 & 100,0 \\
\hline Цефтриаксон, 30 мкг & 42,8 & 67,6 & 83,3 & 44,4 & 0,0 & 66,7 & 33,3 \\
\hline Цефуроксим, 30 мкг & 71,4 & 82,3 & 83,3 & 77,8 & 30,0 & 33,3 & 66,7 \\
\hline Гентаміцин, 10 мкг & 87,7 & 88,2 & 83,3 & 72,2 & 100,0 & 100,0 & 100,0 \\
\hline Доксициклін, 10 мкг & 0,0 & 76,5 & 50,0 & 38,9 & 60,0 & 33,3 & 66,7 \\
\hline Фурамаг, 300 од. & 0,0 & 97,0 & 83,3 & 83,3 & 60,0 & 66,7 & 100,0 \\
\hline Гатифлоксацин, 5 мкг & 71,4 & 97,0 & 83,3 & 77,8 & 100,0 & 66,7 & 100,0 \\
\hline Ципрофлоксацин, 5 мкг & 71,4 & 91,2 & 66,7 & 72,2 & 100,0 & 100,0 & 100,0 \\
\hline Діоксизоль (діоксидин) & 87,7 & 88,2 & 100,0 & 88,9 & 60,0 & 66,7 & 100,0 \\
\hline Октенісепт, 1 : 1 & 42,8 & 76,5 & 100,0 & 83,3 & 30,0 & 66,7 & 66,7 \\
\hline Бетадин, 10\% & 71,4 & 88,2 & 100,0 & 88,9 & 100,0 & 100,0 & 100,0 \\
\hline Декасан, 0,02\% & 42,8 & 67,6 & 50,0 & 72,2 & 30,0 & 66,7 & 33,7 \\
\hline Хлоргексидин, 0,05\% & 57,1 & 58,8 & 50,0 & 77,8 & 60,0 & 66,7 & 66,7 \\
\hline
\end{tabular}

Найефективнішими серед досліджених антибіотиків виявилися цефалоспорини III і IV покоління: цефепім, цефоперазон і цефтазидим. Ці антибіотики проявляли бактерицидну дію на всі виділені бактерії з ХАТ. Винятком виявилися лише бактерії роду Enterococcus spp., які чутливі до цефтазидиму в $38,9 \%$. Протимікробна активність інших цефалоспоринів хоча й була висока, але значно менша, ніж у цефоперазону та цефтазидиму. Чутливість планктонних форм бактерій до цефтриаксону коливалася у межах 33,3-83,3\%, a Proteus spp. узагалі стійкі до цього препарату. Чутливість виділених бактерій до препарату нітрофуранового ряду - фурамагу - також висока (60-100\%), лише P. aeruginosa проявляла стійкість у 100\% досліджуваних культур.

Аміноглікозид гентаміцин проявляв стабільну бактерицидну дію на всі виділені бактерії, чутливість їх становила 72,2-100,0\%. Ефективність антибіотиків тетрациклінового ряду, зокрема, доксицикліну, низька. Слід відмітити досить високу протимікробну активність у препаратів фторхінолонового ряду гатифлоксацину та ципрофлоксацину. Кількість чутливих до гатифлоксацину штамів P. aeruginosa та Enterobacter spp. становила 71,4\%, всі інші виділені бактерії чутливіші до цього препарату (77,8-100,0\%). Найвища чутливість до ципрофлоксацину була в ентеробактерій - 91,2$100,0 \%$, найменша - у стафілококів і ентерококів - 66,7-72,2\%. Отже, результати визначення чутливості виділеної мікрофлори до антибіотиків мають велике клінічне значення, оскільки дозволяють обгрунтувати вибір раціональної схеми антибіотикотерапії.

Для місцевого лікування хронічних анальних тріщин з антимікробних препаратів найчастіше використовують антисептики.
Ми визначили чутливість виділеної мікрофлори до антисептиків. Із п'яти досліджених антисептиків виявлено найбільшу протимікробну дію у розчинів діоксидину та бетадину (повідонйод), чутливість мікрофлори становила 60,0-100,0\%. Найменш активний відносно виділеної мікрофлори антисептик декасан: чутливість бактерій - 30,0-72,2\%. Враховуючи антимікробну дію антисептиків для місцевого лікування хворих на ХАТ і для внутрішньотканинного електрофорезу тріщин ми використовували розчин «Діоксизоль-Дарниця» (діюча речовина діоксидин).

Мікроорганізми здебільшого перебувають у біоплівках, а планктонна форма призначена для колонізації інших локалізацій. Результати досліджень впливу антимікробних препаратів на бактерії, які сформовані у біоплівки, наведено в таблиці 2. У дослід відібрано штами бактерій, планктонні форми яких чутливі до визначених у досліді антибіотиків у диск-дифузному методі Кірбі - Бауера та антисептиків у луночковому методі.

Як видно $з$ даних таблиці 2, антимікробні препарати (антибіотики та антисептики) проявляли бактерицидну дію до мікроорганізмів у мікробній біоплівці, проте мікробні клітини виявлялися життєздатними на рівні вище «порогу інфікованості». Найбільше захищені біоплівкою виявилися клітини P. aeruginosa та Enterococcus spp. Із досліджених антимікробних засобів найкраще впливає на клітини в біоплівці гатифлоксацин. Після дії гатифлоксацину на біоплівки P. aeruginosa та Enterococcus spp. кількість живих клітин не перевищувала $\lg 1,5 \pm 0,1 \mathrm{KУO} / \mathrm{cm}^{2}$ площі біоплівки, а клітини S. aureus i E. coli повністю інактивовані. За дії інших антибіотиків кількість мікробних клітин, що вижили, не перевищувала $\lg 2,9 \pm 1,6$ КУО/см² площі біоплівки. 3 антисептиків на бактерії у 
біоплівках найкраще діяв діоксидин: кількість життєздатних мікробних клітин становила $\lg 2,9 \pm 1,7 \mathrm{KУO} / \mathrm{cm}^{2}$ площі біоплівки. Інші антисептики (октенісепт, декасан і хлоргексидин) проявляли меншу бактерицидну дію на клітини у біоплівках, кількість бактерій, що вижили після їх дії, становила від $\lg 2,9 \pm 1,8$ до $\lg 3,7 \pm$ 2,2 КУО/см² площі біоплівки.

Таблиця 2

Вплив антимікробних препаратів на бактерії у складі біоплівки $\left(\lg K У О / \mathrm{cm}^{2}, \mathrm{x} \pm \mathrm{SE}\right)$

\begin{tabular}{|c|c|c|c|c|c|c|c|c|}
\hline \multirow{2}{*}{$\begin{array}{c}\text { Антимікробні } \\
\text { препарати, кількість } \\
\text { діючої речовини }\end{array}$} & \multicolumn{2}{|c|}{$\begin{array}{c}\text { Кількість клітин } P \text {. aeruginosa } \\
\text { у біоплівці, } \mathrm{n}=4\end{array}$} & \multicolumn{2}{|c|}{$\begin{array}{l}\text { Кількість клітин E. coli } \\
\text { у біоплівці, } \mathrm{n}=12\end{array}$} & \multicolumn{2}{|c|}{$\begin{array}{c}\text { Кількість клітин S. aureus } \\
\text { у біоплівці, } \mathrm{n}=3\end{array}$} & \multicolumn{2}{|c|}{$\begin{array}{c}\text { Кількість клітин Enterococcus } \\
\text { spp. у біоплівці, } \mathrm{n}=5\end{array}$} \\
\hline & $\begin{array}{c}\text { до дії } \\
\text { препарату }\end{array}$ & $\begin{array}{c}\text { після дії } \\
\text { препарату }\end{array}$ & $\begin{array}{c}\text { до дії } \\
\text { препарату }\end{array}$ & $\begin{array}{c}\text { після дії } \\
\text { препарату }\end{array}$ & $\begin{array}{c}\text { до дії } \\
\text { препарату }\end{array}$ & $\begin{array}{c}\text { після дії } \\
\text { препарату }\end{array}$ & $\begin{array}{c}\text { до дії } \\
\text { препарату }\end{array}$ & $\begin{array}{c}\text { після дії } \\
\text { препарату }\end{array}$ \\
\hline Цефепім, 30 мг/л & $6,6 \pm 4,1$ & $2,8 \pm 1,3$ & $6,5 \pm 4,1$ & $2,8 \pm 1,5$ & $6,7 \pm 4,2$ & $2,8 \pm 1,3$ & $6,7 \pm 4,3$ & $2,9 \pm 1,3$ \\
\hline Цефтазидим, 30 мг/л & $6,6 \pm 4,1$ & $2,3 \pm 1,3$ & $6,5 \pm 4,1$ & $2,2 \pm 1,2$ & $6,7 \pm 4,2$ & $2,3 \pm 1,2$ & $6,7 \pm 4,3$ & $2,8 \pm 1,5$ \\
\hline Цефтриаксон, 30 мг/л & $6,6 \pm 4,1$ & $2,1 \pm 1,2$ & $6,5 \pm 4,1$ & $2,9 \pm 1,3$ & $6,7 \pm 4,2$ & $2,7 \pm 1,4$ & $6,7 \pm 4,3$ & $2,8 \pm 1,5$ \\
\hline Гентаміцин, 10 мг/л & $6,6 \pm 4,1$ & $2,5 \pm 1,4$ & $6,5 \pm 4,1$ & $2,3 \pm 1,9$ & $6,7 \pm 4,2$ & $2,9 \pm 1,5$ & $6,7 \pm 4,3$ & $2,9 \pm 1,6$ \\
\hline Гатифлоксацин, 5 мг/л & $6,6 \pm 4,1$ & $1,5 \pm 0,1$ & $6,5 \pm 4,1$ & 0 & $6,7 \pm 4,2$ & 0 & $6,7 \pm 4,3$ & $1,4 \pm 0,2$ \\
\hline Діоксизоль & $6,6 \pm 4,1$ & $2,8 \pm 1,6$ & $6,5 \pm 4,1$ & $2,8 \pm 1,6$ & $6,7 \pm 4,2$ & $2,8 \pm 1,5$ & $6,7 \pm 4,3$ & $2,9 \pm 1,7$ \\
\hline Октенісепт, 1 : 1 & $6,6 \pm 4,1$ & $3,4 \pm 1,9$ & $6,5 \pm 4,1$ & $2,9 \pm 1,8$ & $6,7 \pm 4,2$ & $2,9 \pm 1,8$ & $6,7 \pm 4,3$ & $2,9 \pm 1,7$ \\
\hline Бетадин, 10\% & $6,6 \pm 4,1$ & $3,7 \pm 2,0$ & $6,5 \pm 4,1$ & $3,3 \pm 1,9$ & $6,7 \pm 4,2$ & $3,0 \pm 2,0$ & $6,7 \pm 4,3$ & $3,2 \pm 2,1$ \\
\hline Декасан, $0,02 \%$ & $6,6 \pm 4,1$ & $3,7 \pm 2,2$ & $6,5 \pm 4,1$ & $2,9 \pm 1,3$ & $6,7 \pm 4,2$ & $3,1 \pm 1,6$ & $6,7 \pm 4,3$ & $3,2 \pm 2,1$ \\
\hline Хлоргексидин, 0,05\% & $6,6 \pm 4,1$ & $3,5 \pm 1,7$ & $6,5 \pm 4,1$ & $2,9 \pm 1,3$ & $6,7 \pm 4,2$ & $3,0 \pm 1,6$ & $6,7 \pm 4,3$ & $3,0 \pm 2,1$ \\
\hline
\end{tabular}

Отже, бактерії у біоплівках стійкіші до антимікробних препаратів, ніж їх планктонні форми. Оскільки, за даними різних авторів (Iftodij et al., 2014; Ebinger et al., 2017; Stewart et al., 2017; Wienert et al., 2017), хронічні рани здебільшого загоюються упродовж тривалого часу, можна стверджувати, що мікроорганізми, що виділяються 3 цих ран, перебувають у біоплівці та ускладнюють протимікробну терапію.

Із метою обгрунтування ефективності лікування ХАТ за допомогою внутрішньотканинного електрофорезу 3 діоксизолем вивчали вплив різної сили струму на деградацію біоплівки (табл. 3). За дії електрофорезу силою струму $0,05 \mathrm{~mA} / \mathrm{cm}^{2}$ площі біоплівки, їх щільність зменшувалася в середньому в 1,62,0 раза $(\mathrm{P}>0,05)$. Із підвищенням сили струму до $0,1 \mathrm{~mA} / \mathrm{cm}^{2}$ площі щільність біоплівки суттєво зменшувалася, що вказує на руйнування екзополісахаридного матриксу. Найсильніша деградація біоплівки відбулася в Enterobacter spp.: зменшення відбулося у 2,8 раза $(\mathrm{P}>0,05)$, порівняно 3 контролем. У S. aureus, E. coli та Enterococcus spp. щільність біоплівок знизилася в 2,4 2,5 раза $(\mathrm{P}>0,05)$. Найстійкішими до дії електрофорезу $0,1 \mathrm{~mA} / \mathrm{cm}^{2}$ площі біоплівки виявилися бактерії виду $P$. aeruginosa - щільність біоплівок зменшилася в 1,9 раза.

Для лікування ХАТ із метою руйнування мікробної біоплівки та кращого бактерицидного впливу лікарських засобів проведено гальванізацію 3 розчином «Діоксизоль-Дарниця». Результати досліджень впливу електрофорезу з діоксизолем за різної сили струму на мікробні біоплівки наведено в таблиці 4. У дослід взято штами бактерій, планктонні форми яких чутливі до діоксизолю у луночковому методі.

Таблиця 3

Вплив електрофорезу силою струму 0,05-0,1 мА/см² площі чашки Петрі та тривалістю 60 хвилин на мікробні біоплівки $(\mathrm{x} \pm \mathrm{SE} ; \mathrm{n}=27)$

\begin{tabular}{lccc}
\hline \multirow{2}{*}{ Вид бактерій } & \multicolumn{3}{c}{ Щільність мікробних біоплівок } \\
\cline { 2 - 5 } & $\begin{array}{c}\text { до дії електрофорезу, } \\
\text { од. (контроль) }\end{array}$ & $\begin{array}{c}\text { після дії електрофорезу силою струму } \\
0,05 \mathrm{~mA} / \mathrm{cm}^{2} \text { площі біоплівки, од. }\end{array}$ & $\begin{array}{c}\text { дії електрофорезу, після дії електрофорезу силою струму } \\
\text { одонтроль) }\end{array}$ \\
\hline P. aeruginosa, $\mathrm{n}=4$ & $1,7 \pm 0,1$ & $1,1 \pm 0,04^{*}$ & $1,8 \pm 0,1$ \\
S. aureus, $\mathrm{n}=3$ & $1,8 \pm 0,1$ & $1,0 \pm 0,04^{*}$ & $1,7 \pm 0,1$ \\
E. coli, $\mathrm{n}=12$ & $1,4 \pm 0,1$ & $0,9 \pm 0,05^{*}$ & $1,4 \pm 0,1$ \\
Enterococcus spp., $\mathrm{n}=5$ & $1,8 \pm 0,1$ & $1,1 \pm 0,03^{*}$ & $1,8 \pm 0,1$ \\
Enterobacter spp., $\mathrm{n}=3$ & $1,3 \pm 0,1$ & $0,7 \pm 0,04^{*}$ & $1,4 \pm 0,1$ \\
\hline
\end{tabular}

Примітка: * - $\mathrm{P}>0,05$, щодо контолю.

\section{Таблиця 4}

Кількість бактерій у біоплівці до та після дії електрофорезу з діоксизолем із різною силою струму $\left(\lg\right.$ КУО/ $\left./ \mathrm{cm}^{2}, \mathrm{x} \pm \mathrm{SE} ; \mathrm{n}=27\right)$

\begin{tabular}{|c|c|c|c|c|}
\hline Вид бактерій & $\begin{array}{c}\text { Кількість бактерій на } 1 \text { см² площі } \\
\text { біоплівки до електрофорезу }\end{array}$ & $\begin{array}{c}\text { Кількість бактерій після дії } \\
\text { силою струму } 0,025 \mathrm{MA} / \mathrm{cm}^{2} \\
\text { площі біоплівки }\end{array}$ & $\begin{array}{c}\text { Кількість бактерій після дії } \\
\text { силою струму } 0,05 \mathrm{~mA} / \mathrm{cm}^{2} \\
\text { площі біоплівки }\end{array}$ & $\begin{array}{c}\text { Кількість бактерій після дії } \\
\text { силою струму } 0,1 \mathrm{~mA} / \mathrm{cm}^{2} \\
\text { площі біоплівки }\end{array}$ \\
\hline P. aeruginosa, $\mathrm{n}=4$ & $6,7 \pm 5,2$ & $2,3 \pm 1,2^{*}$ & не виділено & не виділено \\
\hline S. aureus, $\mathrm{n}=3$ & $6,8 \pm 5,3$ & $1,4 \pm 0,3^{*}$ & не виділено & не виділено \\
\hline E. coli, $\mathrm{n}=12$ & $6,6 \pm 5,2$ & $1,5 \pm 0,3^{*}$ & не виділено & не виділено \\
\hline Enterococcus spp., $\mathrm{n}=5$ & $6,7 \pm 5,2$ & $2,2 \pm 0,9 *$ & не виділено & не виділено \\
\hline Enterobacter spp., $\mathrm{n}=3$ & $6,4 \pm 5,1$ & не виділено & не виділено & не виділено \\
\hline
\end{tabular}

Примітка: див. табл. 3.

Із таблиці 4 видно, що застосування електрофорезу з антисептиком діоксидином на мікробні біоплівки досить дієвий. За сили струму $0,05-0,10 \mathrm{~mA} / \mathrm{cm}^{2}$ площі біоплівки бактерій не виділено. Це вказує на руйнування біоплівки також добрий контакт діоксидину з мікробними клітинами та прояв бактерицидної дії.

\section{Обговорення}

Нині достеменно з'ясовано, що хронічні гнійно-запальні процеси спричиняються мікроорганізмами у біоплівці, та традиційна етіотропна антибактеріальна терапія малоефективна (Penesyan et al., 2015; Banin et al., 2017). Тому науковці прово- дять пошук дієвих методів і засобів впливу на бактерії у біоплівках із метою ефективного лікування запальних процесів. Наші дослідження виявили, що чутливість планктонних форм бактерій, виділених із ХАТ, до антибіотиків цефалоспоринів: цефепім, цефоперазон і цефтазидим становила 71,4-100,0\%. Тільки ентерококи були стійкими до цефтазидиму (чутливість 38,9\%). Чутливість виділених бактерій до гентаміцину також була високою (72,4-100,0\%), як і до фторхінолонів (гатифлоксацину та ципрофлоксацину - 66,7-100,0\%). У дослідженнях (Hidijatov et al., 2012; Wienert et al., 2017) також вказується на високу чутливість (73,4-100,0\%) мікрофлори ХАТ до антибіотиків цефалоспоринів і аміноглікозидів. Незважаючи на значну 
чутливість планктонних форм бактерій, виділених із ХАТ, до антибіотиків, не завжди досягається позитивний результат під час лікування (Castillo and Margolin, 2004; Ebinger et al., 2017; Stewart et al., 2017), оскільки в патогенезі ХАТ провідна роль належить біолівковим формам бактерій (Iftodij et al., 2014; Nedashkivs'ka et al., 2016). Ці дослідження збігаються з численними даними про необхідність визначення чутливості мікрофлори до антибіотиків під час лікування гнійно-запальних процесів. За нашими даними, антисептики менш дієві на планктонні форми бактерій, ніж антибіотики, що ймовірно пов'язано 3 частішим застосуванням їх для місцевого лікування ХАТ. Чутливість планктонних форм бактерій до антисептиків діоксидину та бетадину становила $60,0-100,0 \%$, до розчинів октенісепту, декасану та хлоргексидину - 33,7-83,3\%.

Під час визначеня впливу антибіотиків i антисептиків на біоплівкові форми бактерій встановлено, що клітини у біоплівці стійкіші до антибактеріальних препаратів. Із досліджених антибіотиків найкраще діяв гатифлоксацин ймовірно завдяки його низькій молекулярній масі та здатності проникати через пори та канали біоплівки до мікробних клітин. Після дії гатифлоксацину на біоплівки $P$. aeruginosa та $E$. feacalis кількість живих клітин не перевищувала $\lg 1,5 \pm 0,02 \mathrm{KУO} / \mathrm{cm}^{2}$ змиву, а клітини S. aureus i E. coli повністю інактивовані. Про те, що фторхінолони легко дифундують через біоплівку та ефективно знижують їі ріст і бактерицидно діють на мікробні клітини, повідомляють також автори, які проводили досліди in vitro (Brooun et al., 2000; Stepanovic et al., 2000; Lewis, 2001). Також про підвищену стійкість бактерій у біоплівці, виділених із хронічних ран, до антибіотиків повідомляють дослідження інших авторів (Flemming and Wingender 2010; Sanchez et al., 2013; Sanchez-Vizuete et al., 2015).

Iз досліджених нами антисептиків найкраще діяв на бактеpiї у біоплівках «Діоксизоль-Дарниця» - кількість життєздатних мікробних клітин зменшувалася до $\lg 2,9 \pm 1,6$ на см² площі біоплівки. Бар'єрну функцію екзополісахаридного матриксу щодо антисептиків, зокрема, перекису водню, описано у дослідженнях (Elkins et al., 1999; Hassett et al., 1999), які вказують, що планктонні клітини гинули за концентрації 50 мкМ, а бактерії у біоплівці ефективно захищені, оскільки доза, яка доходила до клітин біоплівки, була нижчою бактерицидного рівня. Це дає змогу стверджувати, що саме здатність бактерій, виділених зі слизової оболонки ХАТ, формувати біоплівку високої щільності ускладнює ефективність протимікробної терапії хвороби та визначає хронічний характер її перебігу. Тому, 3 метою обгрунтування ефективності лікування ХАТ за допомогою внутрішньотканинного електрофорезу 3 діоксизолем, ми вивчали вплив різної сили струму на бактерії у біоплівках $\mathrm{i}$ деградацію біоплівки.

За дії електрофорезу силою струму 0,025-0,100 мА $/ \mathrm{cm}^{2}$ площі відбулося руйнування матриксу біоплівки та його щільність зменшувалася з високої до низької. Однак за дії сили струму $0,025 \mathrm{~mA} / \mathrm{cm}^{2}$ площі біоплівки та діоксидину ще виділялися життєздатні клітини з біоплівки, що вказує на часткове руйнування матриксу. Підвищення сили струму до 0,05-0,10 мА/см² площі біоплівки спричиняло загибель клітин бактерій. Деградація матриксу біоплівки електрофорезом позбавляє мікробні клітини захисту, а застосування препарату «Діоксизоль-Дарниця» забезпечує бактерицидний ефект. Del Pozo et al. (2009) також вказують на ефективність і перспективність використання фізичних методів для боротьби з бактеріями, які перебувають у біоплівці. Електричні поля низької напруги підвищували ефективність антисептиків, їх бактерицидна концентрація на біоплівкові форми бактерій нижча, ніж мінімальна бактерицидна концентрація для планктонних форм. Дослідники (Huang et al., 1996) продемонстрували ефективність ультразвуку щодо біоплівок P. aeruginosa - обробка підвищувала дію гентаміцину відносно тих самих біоплівок. Таким чином, лабораторні мікробіологічні дослідження вказують, що використання електрофорезу здіоксизолем для лікування ХАТ перспективне та актуальне.

\section{Висновки}

Iз XАТ виділяються умовно-патогенні бактерії, планктонні форми яких чутливі до антибіотиків цефалоспоринів III-IV покоління та фторхінолонів (66,7-100,0\%). Чутливість цієї мікрофлори до антисептиків діоксидину та бетадину становила 60,0-100,0\%, а до антисептиків октинісепту, декасану та хлоргексидину - 33,7-83,3\%. Біоплівкові форми бактерій, виділені 3 ХАТ, стійкіші до антибіотиків i антисептиків, ніж їх планктонні форми. Із досліджених антибіотиків найкраще діяв на бактерії у біоплівках гатифлоксацин, після його впливу на біоплівки $P$. aeruginosa та E. feacalis кількість клітин не перевищувала $\lg 1,5 \pm 0,02 \mathrm{KУO} / \mathrm{cm}^{2}$ змиву, а бактерії $S$. aureus i E. coli повністю інактивовані. Із п’яти досліджених антисептиків найефективніше діяв на бактерії у біоплівці діоксидин. Після його впливу кількість мікробних клітин не перевищувала $\lg 2,9 \pm$ $1,7 \mathrm{KУО} / \mathrm{cm}^{2}$ площі біоплівки.

За дії електрофорезу силою струму $0,05 \mathrm{~mA} / \mathrm{cm}^{2}$ площі біоплівки їх щільність зменшувалася в середньому в 1,6-2,0 раза, а за дії силою $0,1 \mathrm{~mA} / \mathrm{cm}^{2}$ площі в 2,4-2,8 раза, що вказує на значну деградацію біоплівки. Завдяки застосуванню електрофорезу силою струму $0,05-0,10 \mathrm{~mA} / \mathrm{cm}^{2}$ площі біоплівки 3 діоксидином відбувається руйнування біоплівки та прояв бактерицидної дії антисептика. Враховуючи отримані дані, у комплексному лікуванні ХАТ рекомендовано проводити внутрішньотканинний електрофорез силою струму $0,05-0,10 \mathrm{MA} / \mathrm{cm}^{2} 3$ антисептиком і призначати антибактеріальну терапію, попередньо визначивши чутливість до антибіотиків і антисептиків, виділених із тріщини мікроорганізмів.

\section{References}

Atkinson, S., \& Williams, P. (2009). Quorum sensing and social networking in the microbial world. Journal of the Royal Society Interface, 6, 959-978.

Banin, E., Hughes, D., \& Kuipers, O. P. (2017). Bacterial pathogens, antibiotics and antibiotic resistance. FEMS Microbiology Reviews, 41(3), 450-452.

Bessa, L. J., Fazii, P., Di Giulio, M., \& Cellini, L. (2015). Bacterial isolates from infected wounds and their antibiotic susceptibility pattern: Some remarks about wound infection. International Wound Journal, 12(1), 47-52.

Brooun, A., Liu, S., \& Lewis, K. (2000). A dose-response study of antibiotic resistance in Pseudomonas aeruginosa biofilms. Antimicrobial Agents and Chemotherapy, 44(3), 640-646.

Castillo, E., \& Margolin, D. A. (2004). Anal fissures: Diagnosis and management. Techniques in Gastrointestinal Endoscopy, 6(1), 12-16.

Cooper, R. A., Bjarnsholt, T., \& Alhede, M. (2014). Biofilms in wounds: A review of present knowledge. Journal of Wound Care, 23(11), 570-582.

Cucarella, C., Tormo, M. A., Ubeda, C., Trotonda, M. P., Monzon, M., Peris, C., Amorena, B., Lasa, I., \& Penades, J. R. (2004). Role of biofilm-associated protein bap in the pathogenesis of bovine Staphylococcus aureus. Infection and Immunity, 72(4), 2177-2185.

Del Pozo, J. L., Rouse, M. S., Mandrekar, J. N., Sampedro, M. F., Steckelberg, J. M., \& Patel, R. (2009). Effect of electrical current on the activities of antimicrobial agents against Pseudomonas aeruginosa, Staphylococcus aureus, and Staphylococcus epidermidis biofilms. Antimicrobial Agents and Chemotherapy, 53(1), 35-40.

Ebinger, S. M., Hardt, J., Warschkow, R., Schmied, B. M., Herold, A., Post, S., \& Marti, L. (2017). Operative and medical treatment of chronic anal fissures A review and network meta-analysis of randomized controlled trials. Journal of Gastroenterology, 52(6), 663-676.

Elkins, J. G., Hassett, D. J., Stewart, P. S., Schweizer, H. P., \& McDermott, T. R. (1999). Protective role of catalase in Pseudomonas aeruginosa biofilm resistance to hydrogen peroxide. Applied and Environmental Microbiology, 65(10), 4594-4600.

Flemming, H. C., \& Wingender, J. (2010). The biofilm matrix. Nature Reviews Microbiology, 8(9), 623-633.

Fuente-Nunez, C., Reffuveille, F., Fernandez, L., \& Hancock, R. E. (2013). Bacterial biofilm development as a multicellular adaptation: Antibiotic resistance and new therapeutic strategies. Current Opinion in Microbiology, 16(5), 580-589.

Gostev, V. V., \& Sidorenko, S. V. (2010). Bakterial'nye bioplenki i infekcii [Bacterial biofilms and infections]. Zhumal Infektologii, 2(3), 4-15 (in Russian).

Hall-Stoodley, L., \& Stoodley, P. (2009). Evolving concepts in biofilm infections. Cellular Microbiology, 11(7), 1034-1043. 
Hall-Stoodley, L., Costerton, J. W., \& Stoodley, P. (2004). Bacterial biofilms: From the natural environment to infectious diseases. Nature Reviews Microbiology, 2(2), 95-108.

Hassett, D. J., Ma, J. F., Elkins, J. G., McDermott, T. R., Ochsner, U. A., West, S. E. Huang, C. T., Fredericks, J., Burnett, S., Stewart, P. S., McFeters, G., Passador, L., \& Iglewski, B. H. (1999). Quorum sensing in Pseudomonas aeruginosa controls expression of catalase and superoxide dismutase genes and mediates biofilm susceptibility to hydrogen peroxide. Molecular Microbiology, 34(5), 1082-1093.

Hidijatov, I. I., Adiev, R. F., Strizhkov, A. E., Kazakov, M. V., \& Nurimanov, R. Z. (2012). Rezul'taty kompleksnogo obsledovanija i hirurgicheskogo lechenija bol'nyh s hronicheskoj anal'noj treshhinoj [The results of complex examination and surgical treatment of patients with chronic anal fissure]. Astrahanskij Medicinskij Zhurnal, 7(4), 256-259 (in Russian).

Hoiby, N., Bjarnsholt, T., Givskov, M., Molin, S., \& Ciofu, O. (2010). Antibiotic resistance of bacterial biofilms. International Journal of Antimicrobial Agents, 35(4), 322-332.

Huang, C. T., James, G., Pitt, W. G., \& Stewart, P. S. (1996). Effects of ultrasonic treatment on the efficacy of gentamicin against established Pseudomonas aeruginosa biofilms. Colloids and Surfaces B: Biointerfaces, 6(4-5), 235-242.

Iftodij, A. G., Kozlovska, I. M., Olenovich, O. A., Bilik, O. V., \& Brodovskij S. P. (2014). Vpliv mikroflori kishechniku na patogenez perebigu hronichnih uskladnenih anal'nih trishhin [Influence of intestinal microflora on the pathogenesis of chronic complicated anal fissures]. Bukovinskij Medichnij Visnik, 18(3), 78-82 (in Ukrainian).

Kukhtyn, M., Berhilevych, O., Kravcheniuk, K., Shynkaruk, O., Horyuk, Y., \& Semaniuk, N. (2017). Formation of biofilms on dairy equipment and the influence of disinfectants on them. Eastern-European Journal of Enterprise Technologies, 5(11), 26-33.

Kukhtyn, M., Berhilevych, O., Kravcheniuk, K., Shynkaruk, O., Horyuk, Y., \& Semaniuk, N. (2017). The influence of disinfectants on microbial biofilms of dairy equipment. Eureka: Life Sciences, 5, 11-17.

Lewis, K. (2001). Riddle of biofilm resistance. Antimicrobial Agents and Chemotherapy, 45(4), 999-1007.

Mah, T. F. C., \& O’Toole, G. A. (2001). Mechanisms of biofilm resistance to antimicrobial agents. Trends in Microbiology, 9(1), 34-39.

Manavathu, E. K., Vager, D. L., \& Vazquez, J. A. (2014). Development and antimicrobial susceptibility studies of in vitro monomicrobial and polymicrobial biofilm models with Aspergillus fumigatus and Pseudomonas aeruginosa. BMC Microbiology, 14(1), 53.

Nedashkivska, V. V., Dronova, M. L., \& Vrinchanu, N. O. (2016). Bioplivki ta jih rol' $\mathrm{v}$ infekcijnyh zahvorjuvanniah [Biofilms and their role in infectious diseases]. Ukrajins'kij Naukovo-Medychnij Molodizhnyj Zhurnal, 98, 10-19 (in Ukrainian).
Penesyan, A., Gillings, M., \& Paulsen, I. T. (2015). Antibiotic discovery: Combatting bacterial resistance in cells and in biofilm communities. Molecules, 20(4), 5286-5298.

Percival, S. L., Hill, K. E., Williams, D. W., Hooper, S. J., Thomas, D. W., \& Costerton, J. W. (2012). A review of the scientific evidence for biofilms in wounds. Wound Repair and Regeneration, 20(5), 647-657.

Sanchez, C. J., Mende, K., Beckius, M. L., Akers, K. S., Romano, D. R., Wenke, J. C., \& Murray, C. K. (2013). Biofilm formation by clinical isolates and the implications in chronic infections. BMC Infectious Diseases, 13(1), 47.

Sanchez-Vizuete, P., Orgaz, B., Aymerich, S., Le Coq, D., \& Briandet, R. (2015). Pathogens protection against the action of disinfectants in multispecies biofilms. Frontiers in Microbiology, 6, 1-12.

Soto, S. M. (2013). Role of efflux pumps in the antibiotic resistance of bacteria embedded in a biofilm. Virulence, 4(3), 223-229.

Stepanovic, S., Vukovic, D., Dakic, I., Savic, B., \& Svabic-Vlahovic, M. (2000). A modified microtiter-plate test for quantification of staphylococcal biofilm formation. Joumal of Microbiological Methods, 40(2), 175-179.

Stewart Sr, D. B., Gaertner, W., Glasgow, S., Migaly, J., Feingold, D., \& Steele, S. R. (2017). Clinical practice guideline for the management of anal fissures. Diseases of the Colon and Rectum, 60(1), 7-14.

Van Acker, H., Van Dijck, P., \& Coenye, T. (2014). Molecular mechanisms of antimicrobial tolerance and resistance in bacterial and fungal biofilms. Trends in Microbiology, 22(6), 326-333.

Vorobey, E. S., Voronkova, O. S., \& Vinnikov, A. I. (2017). Korekcija dysbiozu pihvy myshej, vyklykanogo plivkotvirnym shtamom Staphylococcus aureus, za dopomogoju bakteriofagiv i probiotykiv [Correction of vaginal dysbiosis in mice caused by a filmforming strain Staphylococcus aureus, using bacteriophages and probiotics]. Regulatory Mechanisms in Biosystems, 8(2), 252-258 (in Ukrainian).

Vos, P., Garrity, G., Jones, D., Krieg, N. R., Ludwig, W., Rainey, F. A., \& Whitman, W. (Eds.). (2011). Bergey's manual of systematic bacteriology. Vol. 3: The Firmicutes. Springer Science \& Business Media.

Weigel, L. M., Donlan, R. M., Shin, D. H., Jensen, B., Clark, N. C., McDougal, L. K., Zhu, W., Musser, K. A., Thompson, J., Kohlerschmidt, D., Dumas, N., Limberger, R. J., \& Patel, J. B. (2007). High-level vancomycin-resistant Staphylococcus aureus isolates associated with a polymicrobial biofilm. Antimicrobial Agents and Chemotherapy, 51(1), 231-238.

Wienert, V., Raulf, F., \& Mlitz, H. (2017). Anal fissure: Symptoms, diagnosis and therapies. Springer.

Zhao, G., Usui, M. L., Lippman, S. I., James, G. A., Stewart, P. S., Fleckman, P., \& Olerud, J. E. (2013). Biofilms and inflammation in chronic wounds. Advances in Wound Care, 2(7), 389-399. 